\title{
Rethinking Russian Foreign Policy Towards Africa: Prospects and Opportunities for Cooperation in New Geopolitical Realities
}

\author{
H. I. Abdallah, and A. Abdul Salam
}

\begin{abstract}
Diplomatic ties between Africa and the Russian Federation dates back to Africa's dark decades of collective struggle for continental decolonization and severance in relations with its European colonizers. There is a vestige of historical evidence to support the claim that Russia had contributed immensely to this struggle in the early 1950s. Historically, the Russian Revolution of 1917 set the stage for the strenuous global struggle against colonialism and imperialism. This revolution, subsequently, inspired leaders of the nationalist movements on the African continent like Kwame Nkrumah of Ghana, Nnamdi Azikiwe of Nigeria, Haile Selassie of Ethiopia, Nelson Mandela of South Africa and Kenneth Kaunda of Zambia, among others to champion the fight for the liberation of Africa. Between 1945 and 1991, international politics was in a hegemonic geopolitical tension between the Soviet Union and the United States and their respective global allies. This power struggle polarized the world into the contrasting ideologies of Capitalism and Socialism. Some African nationalists situated the crusade for self-rule within the Eastern Bloc led by the Soviet Union. The collapse of the USSR on 26 December 1991 and the fall of the Berlin wall on 9 November 1989 heralded a new era in global politics. This paper is on the assumption that three decades into the demise of the Soviet Union, it is now time to reflect on the influence of Russia in international politics, with particular focus on Moscow's foreign policy towards SubSaharan Africa. This rethinking is crucial because of the criticism that Russia's renewed interest in Africa is a grand strategy to dominate affairs of the continent, rather than a search for new opportunities for economic cooperation and geopolitical alliances.
\end{abstract}

Index Terms - foreign policy, soviet union, africa, russia, arms trade, russia-african summit, diplomacy

\section{INTRODUCTION}

Conventional narratives in the literature have it that the Soviet Union turned its back on the African continent as it imploded in the 1990s. However, nearly three decades after the crumble of the Soviet Union, Russia - under the leadership of President Putin - is reengaging with Africa. The reasons, according to some analysts (mostly Western analysts), are simple: (1) Western sanctions: The United States has imposed sanctions on Russia in response to its invasion of Ukraine, election interference, other malicious cyber activities, human rights abuses, weapons proliferation, illicit trade with North Korea, and support to Syria and

Published on April 30, 2021.

H. I. Abdallah

Department of International Relations

Social Sciences University of Ankara, Turkey.

(e-mail: harunaimam@yahoo.com)
Venezuela [1]. These sanctions may include blocking of assets subject to US jurisdiction; limits on access to the US financial system, including transactions involving US corporations and individuals; and refusal of entry into the United States. The United States also, tightly, controls exports to Russia's Defense and energy sectors; (2) the "pivot to China" hasn't been a success: Moscow's hopes that a new business relationship with Asia would make up for Russia's losses (following the Western sanctions) have not materialized [2]. There was an undue level of optimism in Moscow concerning Chinese corporate organizations. Businesses in Moscow were under the "illusion" that their Beijing's counterparts were willing to spend big money in the Russian market [3]. But the Chinese turned out to be very rational and good business people; so they wouldn't give money away for nothing, and (3) hopes of billions of dollars "in investment from the Middle East haven't arrived in the quantities expected. Since 2007, Russia has increasingly focused on financial tactics to achieve its strategic policy goals in the Middle East". This "soft power" links Russia to the Middle East in new and creative ways, a trend that has continued without let-up since Russian President Vladimir Putin visited the region twice over a decade ago. The climax of the narratives is that Russia wants to use its connections in Africa to sway votes against the United States and its allies in the UN (as the Soviets did in Cold War times) while propagating its pragmatic cooperative agenda and increasing its political clout in the continent - a kind of Cold War redux on African soil [4]; [5].

However, Moscow and its African counterparts insist that dealing with each other diversifies their political and economic alliances. Indeed, the current expansion of economic and military ties, and the heightening of diplomatic relations between African countries and the Kremlin, have become necessary because a growing number of regimes in the continent seek opportunities to minimize growing uncertainty among western actors [5]. As a result, Schumacher and Nitoiu [6] argue that the logic of action of these African countries "[is] rooted in the belief that a possible rapprochement with Russia can be used as a bargaining chip vis-a-vis the United States", the European Union member states and China, as well as a mechanism destined to generate economic and financial gains. This paper is on the assumption that three decades into the demise of the

A. Abdul Salam

Department of Public Administration and Health Services Management University of Ghana, Legon, Ghana.

(e-mail: salaam35@gmail.com) 
Soviet Union, it is time to reflect on the influence of Russia in international politics, with particular focus on Moscow's foreign policy towards Sub-Saharan Africa. This rethinking is crucial because of the criticism that Russia's renewed interest in Africa is a grand strategy to dominate affairs of the continent, rather than a search for new opportunities for economic cooperation and geopolitical alliances. The paper takes the position that there is no credible evidence to support the claim that Russia is in Africa to propagate its strategic cooperative agenda and increase its political clout in the continent.

The discussion in this paper is in three main parts. The preceding part provides a historical survey of Soviet relations with the countries in Africa; abstracting from the welter of economic and political ties what seem to be significant and defining features in those days. The second part puts the spotlight on the 'second coming' of Russia; highlights some aspects of political and economic activities involving Russia and selected African countries in recent years. The second section also discusses Moscow's arms trade in Africa. The final section then deduces some general concluding remarks from the discussion, paying greater attention to how Washington and its allies see Moscow's aggressive moves in Africa.

\section{The History OF SOVIET-AFricA RELATIONS}

Russia's ambitions for, and interests in, the African continent had been varied over many decades dating back to the Tsarist periods. In analyzing the current engagement of Moscow with the continent, we may need to trace antecedents in the late USSR period, as attitudes and relations established then still govern most aspects of recent ties. The death of Josef Stalin in 1953 is often set as the most significant period as far as Russian-African relations are concerned. Until the second half of the $20^{\text {th }}$ century, relations between African states and the Union of Soviet Socialist Republics (USSR) had been insignificant; since the USSR had considered the African states under colonial rule as stooges of the capitalist system. However, the rise in Africa's struggle for self-rule coincided with the change of leadership in the USSR. Thus, the burgeoning of independence movements had triggered or activated the interest of the Soviet Union in supporting these anti-colonial movements while at the same time engaging with the newly-independent states across the continent.

Soviet relations with the countries in Africa (especially, black Africa) have been of considerable interest to many western scholars [7]. The Soviets arrived in Africa at the heights of the Cold War and African decolonization. The presence of the USSR in Africa exhibited an uneasy mixture of sober pragmatism and idealistic aspirations. One can agree with Matusevich [8] that "[T]here are no reasons to doubt the sincerity of the Soviet desire to uphold African independence and thus realize the demands of Soviet anticolonial rhetoric. Concurrently, the Soviet interest in Africa was tied to the overriding concerns of Cold War geopolitical rivalries. Soviet attitudes towards independent Africa fluctuated to reflect both the changes in the general " party line," but also the vagaries of superpower competition". While the cold war scholarship on Soviet involvement in Africa, including sub-Saharan Africa, often stressed its ideological thrust, some post-cold war studies emphasized the importance the Soviets attached to the more pragmatic considerations of geopolitical and economic realism, sometimes well hidden under the shroud of the obligatory Marxist-Leninist rhetoric [9].

However, Soviet engagement with Africa was often questioned by policy analysts as to whether the Union of Soviet Socialist Republics (USSR) had a 'grand design' to dominate the continent; or whether it was an opportunist, strategically reacting to opportunities as they present themselves [10]. Understanding Soviet actions from this either/or dichotomy between the 'grand design' and the 'targets of opportunity' would not be straightforward. As stated above, the Soviet Union had aspirations and policy targets towards Africa [11]. However, goals and policies changed over time both in response to events in Africa and in response to successes and failures of Soviet (and American) policies in other parts of the world. Different institutional and factional players might differ on questions of priorities and objectives, or "overweighing costs and benefits of specific policies and programs". Because of the closed nature of the Soviet system, the difficulties in analyzing Soviet behavior towards Africa had led some observers to simply postulate a set of Soviet global or regional goals that were deduced from what the observers believed to be Soviet ideology or from the Soviet Union's commitments to worldwide expansion. We will resist the urge to deviate into this unending (and sometimes unnecessary) debate.

What we intend to do, at least within the limited space of this paper, is examine the broad structure of Soviet relations with Africa, trying to abstract from the welter of economic and political ties what seem to be significant and defining features [12]; [13]. We will not touch on military-related issues due to the narrowed nature of this platform. This undertaking is no substitute for a close textual analysis of relations with particular countries. However, it is essential to extract from the relationships that the Soviet Union had with African states the most significant overall characteristics; this can be done without necessarily determining motives and intentions.

\section{A. Soviet Political Relations with Africa}

This type of relations is the most fluid and elusive relations that exist between nation-states. Generally, they have to do with all the aspects of inter-state relationships such as bilateral and multilateral treaties and agreements, or personal relations between leaders of those states [14]. Indeed, political ties have broader possible connections. For instance, those relations could be declaratory in nature, "as when states announce their support for each other generally or for specific policy measures" [15]. In such cases and others like them, close political relationships may entail little economic interaction or few military ties [16]; [17]. On the other hand, intensive economic relationships may or may not carry in their wake the political influence of one state over another, although many insist that politics follows economics [18].

In evaluating one country's political influence over another, one might have to differentiate among various policy realms and varying levels of generality. Economic assistance, for instance, may skew macroeconomic policies towards a particular nidus or focal point. Or military assistance may call for some structural operational requirements or a change of military doctrine. One state's participation in structuring the internal security for another state plays a significant role in deciding how long a particular regime stays in power. Military forces on the ground, for example, may intervene to 
help put down a coup attempt. In Angola, for instance, Cuban military force was said to have played an influential role (possibly against the wish of the USSR) in keeping the Neto in power against the Alves faction. Of course, Cuban forces were crucial to the MPLA regime's maintaining power vis-àvis Savimbi's UNITA insurgency in Angola [19]. One could cite examples of outsiders helping African leaders to retain power (France in Senegal, Ivory Coast; France and the United States in Zaire); restoring them to power (France in Gabon; Britain in East Africa); determining factional outcomes or removing a leader from power (Libya in Chad; France in the Central African Empire; Tanzania in Uganda). However, fundamental relations between rulers and the ruled may not be altered by the foreign presence. The reason for this is not farfetched. It is more challenging to change leaders in the short-run than to influence the patterns of authority.

In situating the analysis in the context of this short discussion, it is instructive to note that during the heydays of the Cold War, Africa, Asia, and Latin America were perceived by the Soviet Union as future reserves for socialism, holding the key to the ultimate victory over the forces of the "imperialist West." The zero-sum game of the East-West competition encouraged the United States, on the other hand, to try to foil Soviet ambitions. The result was not unexpected: the two superpowers used the territories of third world countries as "battlefields" to engage in their proxy fights against each other, with the locals often ending up ensnared in protracted and violent struggles that did little to serve their interests [20]; [21]. An African proverb helps capture this scenario metaphorically: "when elephants fight, it is the grass that suffers", meaning that the weak get hurt the most in conflicts between the powerful.

The kind of political relationships between the Soviet Union and the African continent during the 1970s is still mystifying to many contemporary political analysts [22]. It is difficult to determine, for instance, Moscow's foreign policy objectives in the Horn of Africa during the years of the bitter and continuous conflict between Ethiopia and Somalia [23]; [24]. The Horn of Africa is the easternmost extension of African land and is defined (broadly) in this paper as the region that is home to the "countries of Djibouti, Eritrea, Ethiopia, Somalia, Kenya, Sudan, South Sudan, and Uganda. Part of the Horn of Africa region is also known as the Somali peninsula; this term is often used when referring to Somalia and eastern Ethiopia".

In constructing a sequential narrative of the Soviet Union's responses to critical events in the region, original multiarchival documents in the Horn of Africa demonstrate a lack of Soviet foreign policy consistency in the Third World during the Cold War. Internal political developments rather than "grand-design" strategy could account for this [25]. Soviet policies toward the Horn were marked by a unified code of conduct, mixing assertiveness with caution. On the ground, this flexible foreign policy behavior was manifested by a series of cautious responses to local developments in an area considered of ideological, political and geostrategic importance to both superpowers. Therefore, Moscow found herself involved in the early 1960s in Somalia and the late 1970s in Ethiopia not by imposition but by invitation.

\section{B. Soviet Economic Relations with Africa}

Soviet economic foreign policy in the Third World had generated interests in academia for a long time. As far back as the mid-1960s, the Soviet Union supported regimes in newly-independent states such as Ghana, Mali and Guinea. The only political rationale for supporting these regimes was to obtain economic benefits for the USSR [26]. In the case of Ghana, for instance, the NLC (the military regime that ousted Nkrumah's government in 1966), accused Nkrumah of mortgaging the Ghanaian economy to the weak and underdeveloped economies of the Soviet Union and its satellites in Eastern Europe and China. Indeed, before the military takeover, some opposition elements in Ghana maintained that Nkrumah had brought in shoddy goods from the backward economies of Eastern Europe and China, and committed Ghana to sell up to 40 per cent of her cocoa beans to the Soviet Union in return for hardware manufactures that were so sub-standard that there was virtually no market for them in Ghana.

This commercial way of approaching the newlyindependent African states was seen in the parsimonious levels of the USSR assistance to sub-Saharan Africa, in the emergence of the continent as a source of minerals such as bauxite (from Guinea) and copper (from Zambia), in an attempt to establish economic co-operation with 'capitalist oriented' states such as Nigeria, and in the use of arms sales as an earner of hard currency [27]; [28]. These trends became pronounced in the 1980 s due to the precarious condition of the Soviet economy. A burgeoning budget deficit, declining growth rates, and indebtedness to Western creditors provided powerful incentives towards the further restructuring of external economic relations. These difficulties were, in turn, compounded by a growing recognition of the burdensome nature of some third-world commitments. A list of foreign debtors published in the Soviet press in March 1990, for example, indicated that developing countries owed a total of 42,000 million roubles in the form of debts accrued from arms sales and unpaid-for economic assistance and trade credits a sum equivalent to the Soviet Union's entire foreign debt at that time. Unlike India, the largest debtors were states of socialist orientation in sub-Saharan Africa, Angola, Ethiopia, and Mozambique [29]; [8]; [30].

There is no doubt that the accumulation of much of this debt was the consequence of Soviet mismanagement and, notwithstanding the commercialization of relations pursued since the late 1960s, neglect of Soviet economic interests. The Deputy Minister of Foreign Economic Relations, V. N Burmistrov, in an interview in August 1990, for example, complained that foreign aid and arms deliveries had been granted to regimes of socialist orientation often for political reasons, with no consideration of their solvency or ability to make the necessary reimbursements, thereby resulting in a considerable drain on the entire economy [22]. The scale of this neglect, according to one report, was such that the Soviet Union only received some $30-40$ per cent of payments due to it for arms sales.

Such concerns appear particularly appropriate with regards to Angola and Ethiopia. Regarding the former, up until 1990, the cost of aid was borne by the Soviet Union. It paid the salaries of its specialists working in the country and, despite provisions in co-operation agreements for the local financing 
of projects, often met these costs by granting credits [31]. The source of indebtedness, however, was caused by heavy purchases of arms and ammunition. Although paid for by revenues from the sale of oil until the mid-1980s, a decline in the world price of this commodity led Angola to accumulate sizeable arrears during the latter part of the decade, amounting to some 2 million roubles by early I989, according to Soviet figures [32]. During this period, however, Moscow's political objective of supporting the military campaigns of the MPLA regime meant that they paid little attention to obtaining any compensatory payments. Deferment negotiations in 1989 led to Angola's debt rescheduled for 15 years. The situation had even been worse in the case of Ethiopia. The ruinous economic condition of the country meant that the Mengistu regime lacked the ability to pay for Soviet military assistance or the much less significant provision of economic aid, resulting in a substantial amount of debt by the beginning of I989 [33]; [34].

By the turn of the decade, several African countries could not repay all their debts due to unfavorable economic conditions. Thus, the Soviets decided to write off 30 to 50 per cent of the debts. Beneficiary countries included Ethiopia, Angola, Guinea, Mozambique, Burkina Faso, Sierra Leone, Guinea-Bissau and Uganda [35]; [36]. Consequently, when Shevardnadze visited Africa, he held bilateral talks with government officials on how defaulting partners could repay the remaining part of their debts to the USSR [37]; [38]. Commercial promissory notes and the delivery of raw materials as a form of payment in kind were some of the methods suggested [39]. The scope of this paper cannot accommodate all the nuances of the Soviet economic relations across Africa.

\section{Russia's Years of Absence from Africa}

The years that follow the demise of the USSR on 26 December 1991, witnessed a striking decrease in Moscow's foreign policies in Africa. In other words, all bilateral relations between African states and the USSR after the collapse of the latter was, in effect, put on the back burner [40]. The 'new' Russian Federation had a dramatic change in foreign policy as it started to focus on putting its domestic affairs in order amidst a struggling economy and a burning desire to 'fit in' in the post-Cold War international system. Due to the 'instability' at home, state authorities could not formulate a coherent foreign policy for the African continent; and had signaled a draw back from relations with Africa by shutting down multiple cultural centers, three consulates and nine embassies [41].

Boris Yeltsin, the then President of Russia, moved to recover the debts owed by some African states while ceasing to honor all foreign aid agreements signed with some other states in the continent. A plea for debt reliefs or deferred payment options did not get the approval of Moscow. This reversal in policy had sown seeds of disenchantment and bitterness in the hearts of many African leaders. When Russia eventually sought to re-establish relations with the continent, it faced significant obstacles. In contrast to Moscow's retrieval policy in Africa, Beijing markedly increased its reputation and profile in the continent during the same era. Africa had witnessed an exponential increase in Chinese investment in those intervening years [42]; [43]. Since then,
China has become “Africa's largest trade partner and the largest bilateral lender to many African countries, creating an asymmetric power dynamic with the potential for dependency" [44]. According to Vladimir Shubin - the Deputy Director of the Institute for African Studies at the Russian Academy of Sciences, and one of the leading historians of Soviet engagement with the African continent Russian foreign policy toward southern Africa after December 1991 was determined, to a very large extent, by clans or personalities acting in their narrow parochial pursuits [45]. In recent years, however, some academics and government officials in Russia have been convinced that Moscow's re-engagement with Africa has both economic and pragmatic foreign policy advantages. Thus, after decades of abandonment, Russia again regards the African continent "as an important counterbalance to what is perceived by the Kremlin as the West's deep-seated antagonism" towards Russia and its current leadership. It is this rekindled interest in Africa that the ensuing pages seek to explore.

\section{THE 'SECOND COMING’ OF RUSSIA}

It is now an open secret that Moscow is gradually tracing its footsteps back to the African continent. In October 2019, the Kremlin held her first Africa summit in Sochi. Over 6,000 delegates from 104 countries attended this summit, including more than 40 heads of African States [46]. An exhibition was held on the sideline of the forum where cooperation between Russia and African countries was discussed [47]. This Russia-Africa summit generated international attention, raising questions about Russia's new Africa strategy. Many analysts viewed Moscow's African return as part of a new plan to resume the level of regional influence once enjoyed by the Soviet Union and as a step toward reclaiming great global power status.

Indeed, given the frequent reference to Russia's 'return' to Africa, it stands to reason that there must have been a particular period in history when Moscow had severed relations with the African continent. As indicated previously, during the 1990s, Moscow had struggled with enormous domestic issues as it transited from a Soviet political and economic system to a multi-party capitalist one. Africa was no longer regarded by Russia as a foreign policy priority immediately after the Cold War even though the continent had occupied a crucial strategic position during the heydays of the Soviet Union. As the international media's attention fades (perhaps because of the coronavirus pandemic) and the reasons for the summit emerge, it is time to examine Russia's renewed interest in Africa. What does it mean to have Russia back? What are the objectives of Russia in Africa? And with what tools is Moscow pursuing those objectives?

The hibernation of closer ties between Moscow and Africa was, in the early 2000s, replaced by the Kremlin's quest to restore its presence in the region. Perhaps, one could argue that this was spurred by growing concern that India, China, Brazil and more importantly the US were deepening their political and economic relations in Africa to secure access to energy reserves and the untapped natural resources in the continent. Government officials in Moscow were quite explicit in their dictums "as to the benefits of returning to Africa, while persistently repeating the theme of Russia's support to Africa to attempt to re-foster good relationships 
with African states and rebuild trust" [48]. Igor Ivanov, the then Foreign Minister of Russia had this to say in 2001: "Our country played the vanguard role in the decolonization of Africa and helped several countries in their independence struggles; today's African leaders remember that very well" [49].

The re-engagement was late and slow but very strategic. In 2006, Vladimir Putin visited the Republic of South Africa under the banner of "seeking goodwill and trade". The visit, which was the first for a Kremlin leader to sub-Saharan Africa, reunited two old ideological soulmates. That was the beginning of several bilateral engagements with South Africa, Ethiopia and Angola at various levels. For Russia, this visit presented the business community with the opportunity to rely on stable political contacts to establish trade and economic cooperation. Hours after landing in Cape Town and meeting with President Thabo Mbeki, President Putin said at a news conference that Russia had planned multibillion-dollar investments in South Africa, signed a business cooperation agreement and a deal to extend sales of nuclear fuel and technology to South Africa's nascent nuclear power industry [50].

In June 2009, President Dmitry Medvedev led a delegation of 300 men and women from the business community for a selected-nation tour in Africa. This tour took him to Angola, Namibia and Nigeria, among others. This official visit was a further indication of Moscow's fervent desire to re-engage with the continent; explore investment opportunities in the region. Political initiatives included a "Treaty of Friendship and Cooperation" covering joint work in healthcare and intellectual property rights [51]. As the Africa Economic Brief indicates, these visits and accompanying initiatives on humanitarian assistance, conflict resolution and debt relief, were meant to address the Kremlin's marginal importance in the region as compared to China, the EU, India, Brazil and the US. Although trade between Russia and Africa grew tenfold between 1994 and 2008, this was from a minuscule starting point of just $\$ 740$ million annually in the immediate post-Soviet period [31]. In the following pages, we would explore the re-engagement drive further by looking at the political and economic implications.

\section{A. Russia's Political Exploits in Africa}

Politically, Moscow aspires to regain the lost 'trust' and leverage it once enjoyed in Africa during the heydays of the Soviet Union. Building lasting relations with nations (especially, poorer ones) come with a financial commitment, but Russia's current strategy is to achieve her aims at a low cost. In keeping with this, the Kremlin endeavors to keep its presence in the minds of current and future African leaders; through consistent bilateral diplomatic meetings to pave the political roads for a practical economic engagement. One of the viable tools Russia relies on to regain political trust in Africa is, to resurrect the old 'sermon' of Russia's noninvolvement in colonizing the continent. Politicians and academics alike never missed the opportunity to assert that Russia was never a colonial power in Africa; thus, never officially left Africa. During this process, the Kremlin has accented "ideology-free diplomacy" to indirectly counter the United States' policy of global hegemony based on the values of Western-style democracy [52].
Comparatively (and to be fair to Russia), the Kremlin is not the only one who decries those fundamental assumptions that have underpinned American foreign policy since the end of the Cold War. Two prominent American realists - Stephen Walt and John Mearsheimer - have argued that Washington should adopt a more restrained and pragmatic approach to its foreign policy. Walt [52] contends that America's ambitious attempt to reorder world politics (through its fight for the spread of democracy) undermined its position, sowed chaos in several regions, and caused considerable misery in many countries. For Walt, "the Cold War victory has been squandered, and the United States has found itself bearing a disproportionate share of global security burdens with a considerable cost to America's blood and treasure". According to Walt, liberal hegemony, pursued by 'an out-oftouch community of foreign policy VIPs', has failed not only in Iraq, but also heavily miscalculated: fallout from the NATO expansion, the consequences of regime change in Afghanistan, Sudan, Libya, Iraq, Syria and elsewhere, the open-ended "war on terror," the mismanagement of the Middle East peace process, the continuing spread of weapons of mass destruction, and the antidemocratic backlash that has occurred since the 2008 financial crisis.

These two renowned scholars of our time (i.e. Walt and Mearsheimer) are, arguably, the best-known opponents of liberal hegemony from a "realist" perspective. Realism in International Relations emphasizes the role of a state and the distribution of power over the importance of promoting democracy and liberal values. Realists argue that there is no central authority to regulate competing interests in the international system. As a result, "states are locked in a sort of Hobbesian trap of permanent competition, constantly vying for influence over one another". The realists' notion of the international system resonates well in the famous quote of William Butler Yeats [53]: "Things fall apart; the center cannot hold. Mere anarchy is loosed upon the world. The blood-dimmed tide is loosed, and everywhere the ceremony of innocence is lost. The best lack all conviction, while the worst are filled with passionate intensity".

That, perhaps, is the reason why Walt argues that given America's advantages (in terms of global influence), the price of US primacy has been mistakenly perceived by administrations on both ends of the political spectrum to be modest and easily absorbed by the world's largest economy. The excessive desire to promote the admirable attributes of democracy remained one of the unyielding foreign policy objectives of the Bill Clinton, George Walker Bush, Barack Hussein Obama and Donald John Trump's administrations, despite ballooning federal deficits, budget sequesters, cuts in Defence spending and world financial crisis. In the meantime, the Washington DC policy establishment eagerly embraced a singular solution to the world's crisis irrespective of the peculiarity of the problem at hand - that, to keep the liberal order alive, the United States must take the lead in "solving every global issue" and, thus, remain "deeply engaged" in what happens in other jurisdictions around the globe.

Therefore, it makes diplomatic sense that Moscow would want to 'play it safe'. Foreign Minister, Ivanov, in 2001, referred to Russia as a "time tested and reliable ally" for Africa stressing that, unlike other superpowers, Moscow had assisted in achieving independence for the continent [49]. In 
an attempt to assuage fears of Russian political activities in sub-Saharan Africa, in particular, many prominent officials and reputable academics from both sides (Russia and Africa) have stated publicly that Moscow's relationship with Africa will continue to ensure no signs of 'neo-colonial' ambition. However, some analysts still argue that there are traces of limited attempts at exerting Russia's "soft power" in the region. For instance, as part of a global Russian aspiration to leverage the attraction of Russian language and culture, the "Russian Schools Abroad" cultural program plans to open many centers in Algeria, Guinea, Mali, Kenya, and Sudan [54]. That comes with limited direct aid programs to those countries. In 2009, for instance, the African Coordinating Committee for Economic Cooperation with African Countries (AfroCom) was created to foster increased political and economic cooperation through an international business forum. Consequently, in June 2009, Moscow hosted the first Russian-African inter-parliamentary summit. The summit was heralded by Petr Fradkov - the Deputy Chairman of AfroCom - as the "biggest political event of such extent in the history of Russian-African relations."

From the Western point of view, Moscow's renewed political "excavations" in Africa are aimed at asserting a multipolar international system that seeks to counter the unrestrained influence of global powers in the continent, especially the United States. Washington, in particular, sees Moscow's push in Africa as a strategic challenge. For instance, former White House national security adviser, John R. Bolton, in announcing the new Africa policy of President Donald J. Trump in December 2018, grouped Russia and China as "great power competitors ... rapidly expanding their financial and political influence... [and] deliberately and aggressively targeting their investments in the region to gain a competitive advantage over the United States" [55].

The Kremlin, however, believes that its political engagement with Africa is for symbiotic benefits. On the one hand, Russia desperately needs Africa, which composes nearly a quarter of the UN, to support Moscow-led initiatives for Russia not to appear isolated on the international stage. The political attraction of some specific initiatives should not elude our understanding; in the topical field of cybersecurity, for example, the Russian and Chinese proposals for regulation of "the internet, which are trenchantly opposed by the Euro-Atlantic community, enjoy an often overlooked degree of support in Africa and elsewhere". On the other hand, African nations stand to enjoy Moscow's support in the United Nations Security Council. In 2008, for instance, Russia voted against imposing sanctions and arms embargos on the late Robert Mugabe's Zimbabwe. Vitaliy Churkin, the Russian ambassador to the United Nations, revealed that Moscow had refused to support the imposition of sanctions on Zimbabwe because the southern African country did not pose any apparent security threat to the international community; and that the matter had not spread beyond being a purely domestic issue [56]. In a similar vein, in August 2012, Russian Deputy Foreign Minister, Mikhail Bogdanov, and Special Presidential Envoy to the Middle East and Africa, Mikhail Margelov, travelled to Ethiopia, Liberia, Uganda, Madagascar and Zimbabwe to woo international support for the Kremlin's stance on the political upheavals in Syria. Thus, for Russia, its relationship with African countries is based on "you scratch my back; and I scratch your back" kind of friendship.

\section{B. Economic Opportunities in Africa}

Since the collapse of the USSR and the subsequence demise of the cold war, Russia has grown more confident in her foreign policy objectives. Therefore, the need to explore economic opportunities elsewhere would not be a misplaced priority. Like the argument made for engaging Africa politically, Moscow's economic objectives in Africa are anchored on the notion that both Russia and Africa "need each other" to ensure the "security and sovereignty of 60 per cent of the world's natural resources, which lie in Russia and Africa combined" [57]. As a fleetly growing region, the African continent remains a strategic economic interest to Russia, including a reservoir of natural resources, a destination for profitable investment projects and a "virgin market" for exports of machinery and technical products. To this effect, among the current foreign policy goals of Russia is building sustainable trade and investment relations with the leading countries in the Middle and Near East as well as Africa. Some of Moscow's foreign economic priorities currently ongoing in Africa (though some of them have already been completed) are: (1) prospecting for gas, oil, uranium, and bauxite assets, construction and mining. These are mostly in countries such as Angola, Nigeria, Sudan, South Africa and Namibia. (2) Construction of power facilities hydroelectric power plants on the River Congo (in Angola, Zambia, Namibia, and Equatorial Guinea) and nuclear power plants (in South Africa and Nigeria); (3) creating a floating nuclear power plant, and South African participation in the international project to build a nuclear enrichment center in Russia; (4) construction of railways (in Angola, Guinea and Nigeria); and (5) establishing of Russian trade centers to promote and maintain engineering products from Russia (in Nigeria and South Africa) [58]. See table 1 below for more information on Moscow's current and expected agreements with some African countries in various economic sectors [59]. 
TABLE I: MOSCOW'S CURRENT AND EXPECTED AGREEMENTS WITH SOME AFRICAN COUNTRIES IN VARIOUS ECONOMIC SECTORS

\begin{tabular}{|c|c|}
\hline Agreements & Key African Countries \\
\hline $\begin{array}{l}\text { Natural } \\
\text { Resources }\end{array}$ & $\begin{array}{l}\text { Angola, Botswana, Cameroon, Central African } \\
\text { Republic, Egypt, Ghana, Guinea, } \\
\text { Mozambique, Libya, Nigeria, Sudan, Zambia, } \\
\text { Zimbabwe }\end{array}$ \\
\hline Arms Sales & $\begin{array}{l}\text { Algeria, Angola, Burkina Faso, Cameroon, } \\
\text { Central African Republic, Egypt, Ethiopia, } \\
\text { Libya, Nigeria, Sudan, Uganda, Zambia, } \\
\text { Zimbabwe }\end{array}$ \\
\hline $\begin{array}{l}\text { Security } \\
\text { Cooperation }\end{array}$ & $\begin{array}{l}\text { Angola, Central African Republic, Egypt, } \\
\text { Madagascar, Mozambique, Somalia, } \\
\text { Somaliland, South Africa, Sudan }\end{array}$ \\
\hline $\begin{array}{l}\text { Counter- } \\
\text { Terrorism }\end{array}$ & Chad, Nigeria, Somalia \\
\hline $\begin{array}{l}\text { Nuclear Power } \\
\text { Technology }\end{array}$ & $\begin{array}{l}\text { Angola, Egypt, Ethiopia, Namibia, Rwanda, } \\
\text { South Africa, Sudan, Zambia }\end{array}$ \\
\hline $\begin{array}{l}\text { Hydropower } \\
\text { Construction }\end{array}$ & Angola, Equatorial Guinea, Namibia, Zambia \\
\hline $\begin{array}{l}\text { Railway } \\
\text { Construction }\end{array}$ & Angola, Guinea, Nigeria \\
\hline
\end{tabular}

\section{On Minerals}

Africa represents a "strategic interest" for Russia in terms of unimpeded access to natural resources. It is projected that within a decade or so, many of Moscow's mineral reserves essential for economic growth such as manganese, zinc, copper, platinum and nickel will be depleted. Although there are vast unexploited natural resource deposits in Russia, there are often very costly to access and extremely difficult to develop. In lieu of this, and given the unpredictability of prices of commodities in the world market, it makes economic sense for Russia to look elsewhere for the supply of such strategic minerals where the costs are lower, in particular, in the Southern African Development Community (SADC) nations [51]. That may be partly why most Russian economic expansion into Africa has been, primarily, centered around those industries where "Russian companies have been most active and successful domestically in the post-Soviet period, namely extraction of ferrous and nonferrous metals", diamonds, and energy [31].

\section{On Energy}

Russia is said to hold the world's largest natural gas reserves; and is one of the two most exporters of oil in the world. The other country is Saudi Arabia. Petroleum, Gas and refined oil products account for two-thirds of Russian exports [60]. However, the level of active reserves for these vital economic resources is constantly falling, while reserves that are difficult to access are rising [61]. Therefore, the Kremlin must secure further oil and gas reserves if it wants to effectively implement its energy policy and continue to support the annual budget. Hence, Russian-African cooperation is expected to play a crucial role in meeting the goals of Russia's energy strategic plan for the year 2030 [49]. This domestic problem is further aggravated by external pressures on Russia in the energy sector. As Barka and Mlambo [31] noted:
Europe's increasing consumption of energy and dependence on oil and gas imports from Russia puts pressure on the Kremlin to seek alternative sources of energy. Africa, with its rich endowment of crude oil reserves, natural gas deposits, and other minerals, is exerting a strong attraction for Russian energy companies .... As Africa's comparative advantage in the scope and frequency of new discoveries is being courted by global energy consumption countries such as Russia, precautionary measures should be put in place to ensure that sustainable economic and social benefits accrue from natural resources exploitation.

In recent years, energy reserves in sub-Saharan African countries have become the center of attraction for producers from Russia and elsewhere. As the U.S. Department of Energy Information Administration has indicated, "Angola is the second-largest oil producer in sub-Saharan Africa behind Nigeria", and explorations in recent years suggest that oil and natural gas reserves in Angola could be more than initially estimated. Industry estimates of proved, probable and possible "current producible reserves" are roughly 35 billion barrels of crude oil and 151 trillion cubic feet of gas, and the US Geological Survey (USGS) estimates that the subSaharan region as a whole could hold 72 billion barrels of undiscovered resource potentials [62]. Although it is unclear when Russian oil production in the continent will peak, lower production costs in Africa would be very attractive for Russian energy companies. Strategically, Moscow links its energy needs with debt and exports of military equipment to broker lucrative deals in Africa. For instance, during a highprofile official visit to Algeria in 2006, President Putin signed a 7.5-billion-dollar deal for missiles, tanks, and a combat aircraft. That deal was linked to a five-billion-dollar debt cancellation to Algeria. During the same visit, Gazprom and Lukoil secured oil and gas concessions in Algeria. The lists could go on, but this limited space would not allow for prolonged analysis on the energy sector.

\section{E. On Trade}

When we compare to other developed countries and many emerging markets globally, Russia and Africa do not seem to have much happened between them as trading partners. Commercial transactions between the two parties were at its peak in 2008 with a total trade volume of $\$ 7.3$ billion. From an African perspective, this amount looks huge. However, although it was about a 10-fold upward adjustment from $\$ 740$ million in 1994, this would not be sufficient to guarantee Moscow a bargaining edge when engaging with African countries. Comparatively, China and the U.S. did much better than Russia in terms of trade volumes. In 2012, for instance, an amount of $\$ 93.2$ billion exchanged 'hands' between Africa and the United States [63]. In that same year, the volume of trade between China and Africa amounted to $\$ 163.9$ billion in the first ten months. Since then, China has been doing up to a 20 per cent increase each year.

Historically, dating back to the Soviet era, South Africa has always been a strong trading partner with Russia. This trajectory has not changed much - at least for sub-Saharan Africa. Annual bilateral trade value between Russia and South Africa increased by 0.5 per cent to $\$ 519.1$ million in 
2010. That notwithstanding, there was a dramatic downward trend in export trade from Russia. The volume of exports fell by 74.5 per cent to $\$ 45.8$ million from $\$ 195.2$ million in 2009 . However, in the first half of 2011, bilateral trade turnover amounted to $\$ 234$ million, showing a growth of 7.9 per cent compared to the same period of the previous year. One might call this a recovery, but that is nothing compared to bilateral trade value between China and South Africa within the same fiscal year, which was about ZAR188 billion. Indeed, available data suggest that bilateral trade agreement between Moscow and the rainbow nation is the smallest among the BRIC nations - Brazil, Russia, India, and China.

In arms trade, Moscow has, since 2003, demonstrated an intention to revive its military cooperation and arms sales to Africa. As the second-largest supplier of arms in the world (behind the United States), Russia is already a major supplier of arms to African countries. China and the US are also crucial weapons suppliers in Africa, but they fall behind Russia, which supplied $49 \%$ of Africa's imported arms between 2013 and 2017. That is, nearly, twice the volume of those purchased from the United States (14\%) and China (13\%) [64]. Moscow does not miss any opportunity to expand its arms deals with the continent. Although deals in nuclear energy, oil, gas, agriculture, and diamonds dominated the discussions in the 2019 Russia-Africa Summit in the Black Sea city of Sochi, two of the main "attractions for African heads of state were military cooperation and military hardware" [65]. The Russian president, Vladimir Putin, after giving his introductory address at the summit argued that arms deals with the 'modern' Russia offered African states their "real independence", implying that deals with former colonial powers such as France and the United Kingdom or global powers like the United States or China come with undesirable conditions in one way or another. After the summit, Nigeria purchased 12 MI-35 Attack Helicopters and signed a deal for training and equipment; other countries also negotiated for more deals to "add to the 21 military agreements signed in the last five years between Russia and Africa". Currently, Russia has military cooperation with South Africa, Burkina Faso, Mali, Sudan, Suriname and the Republic of the Congo, which brings the total number of agreements to over100 in sub-Saharan Africa. Between 2015 and 2019, twelve heads of state from sub-Saharan Africa alone have visited Russia (six of them in 2018) to either initiate new, or cement existing, bilateral or multilateral trade deals. See table 2 below [66].
TABLE II: AFricAn HEADS OF STATE OfFICIAL Visits to RuSSIA, SinCE

\begin{tabular}{|c|c|c|}
\hline Country & President & Dates \\
\hline South Africa & Jacob Zuma & 2015 \\
\hline Zimbabwe & Robert Mugabe & 2015 \\
\hline Sudan & Omar al-Bashir & $2015,2017,2018$ \\
\hline Guinea & Alpha Condé & 2016,2017 \\
\hline $\begin{array}{l}\text { Central African } \\
\text { Republic }\end{array}$ & $\begin{array}{l}\text { Faustin-Archange } \\
\text { Touadéra }\end{array}$ & 2018 \\
\hline Rwanda & Paul Kagame & 2018 \\
\hline Gabon & $\begin{array}{l}\text { Ali Bongo } \\
\text { Ondimba }\end{array}$ & 2018 \\
\hline Senegal & Macky Sall & 2018 \\
\hline Zimbabwe & $\begin{array}{l}\text { Emmerson } \\
\text { Mnangagwa }\end{array}$ & 2019 \\
\hline Angola & João Lourenço & 2018,2019 \\
\hline Congo & $\begin{array}{l}\text { Denis Sassou } \\
\text { Nguesso }\end{array}$ & 2019 \\
\hline Mozambique & Filipe Nyusi & 2019 \\
\hline
\end{tabular}

Available data suggest that Moscow's aggressive moves to dominate the arms trade in Africa extends to all parts of the continent. In North Africa, for instance, Algeria has acquired $12 \mathrm{Su}-34$ bombers and Terminator II combat vehicles from Russia and is reportedly planning to buy a dozen $\mathrm{Su}-57$ jets. Between 2013 and 2015, the country bought $42 \mathrm{Mi}-28 \mathrm{~N}$ combat helicopters, $8 \mathrm{Mi}-26$ transport helicopters and two Project 636 Varshavyanka (Kilo-class) submarinesOuarsenis and Hoggar. Algeria and Russia have had good mutual relations during the Soviet era. Between 1962 and 1989, Algeria spent about 11 billion dollars on some of the most sophisticated Soviet armaments such as tanks, aircraft, various ships, small arms and ammunition. However, the collapse of the Soviet Union, coupled with the civil war that had engulfed Algeria in the 1990s, had negatively affected the bilateral relations between Russia and Algeria.

Although Russia has gained recognition as a global arms supplier, it still lags behind the United States of America. Russia's global sales of weapons decreased by $18 \%$ between 2015 and 2019, while the USA showed a healthy $23 \%$ growth in its exports. It is also no secret that "African nations make up the low end of the arms market with many of them unable to afford Western arms so turn to Russia and China". Though Russia has not made public the mechanism of its arms sales to African nations, it sees the African continent as an opportunity comes in handy for her to explore.

\section{CONCLUSION}

In the forgone paragraphs and pages, we tried to do a content analysis of Russia's renewed foreign policy interest in the African continent after it has allowed its Soviet-era presence in Africa to wither. Since the 2000s, under President Vladimir Putin's leadership, Moscow started courting leaders in the continent to reactivate the relationship it had enjoyed during the Soviet and Cold War epochs.

However, Washington and its allies see Moscow's 'second 
coming' as a strategic challenge. In December 2018, John R. Bolton, the former national security adviser, described the presence of Russia and China in Africa as "great power competitors ... rapidly expanding their financial and political influence ... [and] deliberately and aggressively targeting their investments in the region to gain a competitive advantage over the United States." Bolton continued that Russia and China's "predatory practices ... inhibit opportunities for US investment; interfere with US military operations; and pose a significant threat to US national security interests" [67]. The remarks of the former Trump's White House national security adviser were not isolated. In February 2019, for instance, the then-commander of US Africa Command (AFRICOM), Gen. Thomas D. Waldhauser, also referred to Russia's arms sales and the actions of her semi-private security forces like the Wagner Group in the Central African Republic (CAR) as a "growing challenge". Gen. Waldhauser incriminated Russia of trying to "import harsh security practices, in a region already marred by threats to security, while systematically extracting minerals" and "potentially looks to export their security model regionally" [68]. In April 2019, Gen. Waldhauser's successor, Gen. Stephen Townsend, shared similar concerns when he bemoaned "Russia's malign influence in Africa", and referred to Russian semi-private security forces as the second biggest threat to US security interests in Africa after terrorism [69]. Paul Goble of the Jamestown Foundation also fears that "Moscow may be able to force out Western and Chinese companies ... and restore many of the political positions it enjoyed in Soviet times" [70].

There are many alarmist's reports regarding Russia's renewed foreign policy pursuits in Africa, but citing them all is beyond the goal of this discussion. However, it is significant to note that Moscow's 'return' to Africa is not a "Soviet redux". First, it is not the case that Russia, who is late to the table in the Africa-resource-grab party, would overtake the United States, the European Union and China [71]. All these countries have already established decades-long nurtured relationships across the continent, while Russia is saddled with a burden of distrust after it left most of its old allies hanging in the early 1990s [72]. What is very apparent, instead, is that Moscow is renewing relationships in Africa because it has few alternatives due to sanctions by the US and the EU. Russia is in Africa, not because it wants to make headway in some Cold War-style international competition with the West. Second, Moscow's current sagging economy does not give it the leverage to manipulate decisions in Africa. Though President Putin has succeeded in diversifying the Russian economy, to some extent, it remains heavily dependent on petroleum and other natural resource exports, leaving it vulnerable to any future global recession. Given Russia's 1990s history of deserting African partners when an economic crisis hits at home, rational state leaders in Africa would be hesitant to put all their eggs in one basket.

In short, the Kremlin's intentions in Africa are multifaceted. In certain circumstances, just like other external interlocutors, Russia is pursuing executable investment and trade opportunities in Africa. To achieve this, Russia is presenting itself as a reliable supplier of the much needed technical expertise in Africa, and a dependable partner that Africa can trust. In other contexts, however, Russia could be described as a "rogue actor", bypassing arms embargos, embracing pariah leaders, and blatantly "undermining existing internationally-brokered peace agreements to advance Moscow's leverage" [73]. In some cases, Libya and the Central African Republic, for example, Russia appears to be applying some of the lessons from its experience in the Syrian civil war where support to an isolated leader establishes a dependency relationship that gives Russia enormous regional influence that could prove highly lucrative in the future. However, given its underdeveloped natural resource wealth; emerging markets and strategic location, there is growing interest in Africa among multiple external superpowers, not just Russia.

Whatever the case may be, is the West being fair to Russia? The obvious is that competition for resources, political influence, and access to markets will continue to increase among global powers as finite resources continue to dwindle. Africa is a nest of conflicts that fuel arms sales, a hub of untapped natural resources and an area ripe for cultivating political support for foreign powers. Moscow is only lacing its boots to participate in the game that others have played in Africa for decades if not centuries.

\section{REFERENCES}

[1] S. Paduano. (October, 2019). "Putin Lost His African Great Game Before He Started". IDEAS Institute, [online]. Available at: https://foreignpolicy.com/2019/10/31/putin-russia-africa-great-gamechina-united-states/.

[2] J. Mankoff. "Russia's Asia Pivot: Confrontation or Cooperation?" National Bureau of Asian Research (NBR), No. 19, pp. 65-88, 2015.

[3] A. Gabuev. (2016). "A Pivot to Nowhere: The Realities of Russia's Asia Policy". Carngie Moscow Center, [online]. Available at: https://carnegie.ru/commentary/63408.

[4] J. Mankoff. Russian Foreign Policy: The Return of Great Power Politics. Rowman \& Littlefield Publishers, INC, 2009.

[5] P. Stronski. "Russia's Return to Africa". Carnegie Endowment for International Peace, 2019.

[6] T. Schumacher.and C. Nitoiu. (2015). "Russia's foreign policy towards North Africa in the wake of the Arab Spring" Mediterranean Politics, [online]. Available at: https://www.dahrendorfforum.eu/publications/russias-foreign-policy-towards-north-africa-inthe-wake-of-the-arab-spring.

[7] V. G. Solodovnikov. "Ten Years of the Africa Institute: scientific achievements and tasks of Soviet African studies", in Studies on Developing Countries, Budapest, 55, p. 8. 1971.

[8] M. Matusevich. "Revisiting the Soviet Moment in Sub-Saharan Africa", History Compass 7/5: 1259-1268, 2009. 10.1111/j.14780542.2009.00626.x

[9] M. Matusevich, No Easy Row for a Russian Hoe: Ideology and Pragmatism in Nigerian-Soviet Relations, 1960-1991. Trenton, NJ: Africa World Press, 2003.

[10] H. Bienen. "Perspectives on Soviet Intervention in Africa," Political Science Quarterly, Vol. 95, No. 1, pp. 29-42, 1980.

[11] L. Walter. "The Shifting Line in Soviet Orientalogy", in Problems of Communism, Washington, pp. 21-22, 1956.

[12] A. J. Klinghoffer. The Angolan War: A Study in Soviet Policy in the Third World, Boulder: Westview Pressm, 1980.

[13] R. Legvold. Soviet Policy in West Africa, Cambridge: Harvard University Press, 1970.

[14] P. Suedfeld. "Bilateral Relations between Countries and the Complexity of Newspaper Editorials", International Society of Political Psychology. Vol. 13, No. 4, pp. 601-611, 1992.

[15] H. Bienen. "Soviet Political Relations with Africa". International Security, 6(4), pp. 153, 1982, doi:10.2307/2538682

[16] T. Lychowfki. "Economic Relations between Countries of Different Systems." Indian Economic Review, Vol. 4, No. 1, pp. 114-119, 1958.

[17] L. D. Christina, A. Fuchs and J. Kristina. "State Control and the Effects of Foreign Relations on Bilateral Trade." Journal of Conflict Resolution, pp. 1-34, 2017.

[18] M. Beckley. "Economic Development and Military Effectiveness", The Journal of Strategic Studies, 33:1, 43-79, 2010. 
[19] J. Bervoets. (2011). "The Soviet Union in Angola: Soviet and African Perspectives on the Failed Socialist Transformation", Geohistory, [online]. Available at: https://geohistory.today/soviet-union-angolahistory/.

[20] P. L. Melvyn. For the Soul of Mankind: The United States, the Soviet Union, and the Cold War, Hill and Wang, 2007.

[21] Z. Laidi. The Superpowers and Africa: The Constraints of a Rivalry, 1960-1990. Chicago, IL: The University of Chicago Press, 178-182, 1990.

[22] R. G. Patman. The Soviet Union in the Horn of Africa: The Diplomacy of Intervention and Disengagement, Cambridge University Press 1990.

[23] A. Y. Radoslav. The Soviet Union and the Horn of Africa during the Cold War: Between Ideology and Pragmatism. (The Harvard Cold War Studies Book Series), Lexington Books, 2016.

[24] T. Andargachew. The Ethiopian Revolution 1974-1987: A Transformation from an Aristocratic to a Totalitarian Autocracy, LSE Monographs in International Studies, 1993.

[25] O. O. Mohamed. The scramble in the Horn of Africa. History of Somalia (1827-1977), Somali Publications, 2009.

[26] A. J. Klinghoffer. Soviet perspectives on African socialism, Rutherford [N.J.]: Fairleigh Dickinson University Press, 1969.

[27] O. Atsushi. The Demise of the Soviet Communist Party, Routledge, 2007.

[28] K. K. Kester. (August, 2011). "Russia and Africa: Economic Diplomacy Needs New Strategies,” Russia Beyond the Headlines, [online]. Available at:rbth.ru/articles/2011/08/

17/russia_and_africa_economic_diplomacy_needs_new_strategies 13260.html.

[29] L. Buszynski. Gorbachev and Southeast Asia, Routledge, 2014.

[30] White, S. (1994). After Gorbachev, Cambridge University Press

[31] H. B. Barka. And K. Mlambo. "Russia's Economic Engagement with Africa,” Africa Economic Brief, Vol. 2(7), 2011.

[32] USSR Foreign Ministry. "The Foreign Policy and Diplomatic Activity of the USSR, I989-I990", in International Affairs, 1991.

[33] D. C. Heldman. The USSR and Africa: Foreign Policy Under Khrushchev, New York, NY: Praeger, 1981.

[34] A. Davidson and I. Filatova. "African History: A View from Behind the Kremlin Wall', in M. Matusevich (ed.), Africa in Russia, Russia in Africa: Three Centuries of Encounters. Trenton, NJ: Africa World Press, 111-131, 2006.

[35] M. Radu. And A. J. Klinghoffer, The Dynamics of Soviet Policy in SubSaharan Africa. New York, NY: Holmes \& Meier, pp. 2-3, 1991.

[36] A. R. Amar. An African in Moscow. London: Ampersand, 1965.

[37] G. W. Breslauer. (Ed.). Soviet Policy in Africa: From the Old to the New Thinking. Berkley, CA: Berkley-Stanford Program in Soviet Studies, 1992

[38] D. E. Albright. "The USSR's Policy Toward Africa', in G. W. Breslauer. (Ed.) Soviet Policy in Africa: From the Old to the New Thinking. Berkley, CA: Berkley-Stanford Program in Soviet Studies, pp. 55-56, 1992.

[39] G. Guan-Fu. "Soviet Aid to the Third World, an Analysis of Its Strategy." Soviet Studies 35.1, pp. 71-89, 1983.

[40] I. Alessandro. "The rise and fall of the 'Soviet Model of Development' in West Africa, 1957-64”. Cold War History, Vol. 12, No. 4, pp. 683 704,2012

[41] N. Igho. (2011). “A Review of Russia-Africa Relations: New Challenges and Opportunities," [online]. Available at: myafrica.ru/en/?p=439.

[42] C. Gregory and M. Anton. (2012). "Russia as a Re-Emerging Donor: Catching Up in Africa," [online]. Available at: www.cigionline.org/publications/2012/3/russia-re-emergingdonorcatching-up-africa.

[43] D. Tatyana. (2012). "China is conquering Africa". Moscow, Russia: Russian Council for International Affairs, [online]. Available at: russiancouncil.ru/ inner/?id_4=547.

[44] L. Signé. (January, 2021). How to Restore U.S. Credibility in Africa. Foreign Policy, [online]. Available at: https://foreignpolicy.com/2021/01/15/united-states-africa-bidenadministration-relations-china.

[45] V. Shubin. "ANC - A View from Moscow", Auckland Park, South Africa: Jacana, 2008

[46] S. Lorenzo. (2019). "Russia-Africa: What Has Been Agreed at Sochi Summit?" available at https://www.ispionline.it/it/pubblicazione/russia-africa-what-hasbeen-agreed-sochi-summit-24401.

[47] BBC News (May 7, 2020). "Russia in Africa: What's behind Moscow's push into the continent?" [Online]. Available at: https://www.bbc.com/news/world-45035889.

[48] D. Rosaline and D. Nagar. "Africa and External Actors". Centre for Conflict Resolution, 2016.
[49] I. Natufe (2011). "A Review of Russia-Africa Relations: New Challenges and Opportunities," [online]. Available at: myafrica.ru/en/?p=439.

[50] H. Jean-Christophe and K. François (2015). "Putin in Africa". Egmont Institute, [online]. Available at: https://www.jstor.org/stable/resrep06559.

[51] I. Gerasimchuk. "Re-Think Russian Investment in Southern Africa," WWF's Trade and Investment Programme Report, Moscow, Russia/Johannesburg, South Africa: WWF, p. 32, 2009, [online]. Available at: mpra.ub.uni-muenchen.de/15151/.

[52] S. M. Walt. The Hell of Good Intentions: America's Foreign Policy Elite and the Decline of U.S. Primacy. New York: Macmillan, 2018.

[53] W. B. Yeats. The Collected Poems of W.B. Yeats. Collier Books, 1989

[54] K. Konstantin. (July, 2012). "Conference of ambassadors and permanent representatives of the Russian Federation", [online]. Available at: interaffairs.ru/read. php?item $=8606$.

[55] M. Kimberly (2019). "Russia's Back in Africa: Is the Cold War Returning?". The Washington Quarterly, [online]. Available at: https://doi.org/10.1080/0163660X.2019.1693105.

[56] D. Nawsaw. (July, 2008) "China and Russia Veto Zimbabwe Sanctions". The Guardian, [online]. Available at: www.guardian. co.uk/world/2008/jul/11/unitednations.zimbabwe.

[57] Lavrov, Voice of Russia (October 21, 2011). "Russia-African Union ties have great potential, available at english.ruvr. $\mathrm{ru} / 2011 / 10 / 21 / 59136129 . \mathrm{html}$.

[58] Russian (December, 2008). "Foreign Economic Strategy of the Russian Federation to 2020" [online]. Available at: www.economy. gov.ru/minec/activity/sections/foreigneconomicactivity/vec2020.

[59] www.economy.gov.ru/minec/activity/sections/foreigneconomicactivit $\mathrm{y} / \mathrm{vec} 2020$

[60] O. Olga, C. Keith, H. S. Lowell and Y. Catherin. "Russian Foreign Policy: Sources and Implications", Santa Monica, CA: RAND Corporation, 2009.

[61] M. Dmitry (2009). "Key Elements of Oil Production," Oil of Russia, Vol. 39, No. 2, [online]. Available at: www.oilru.com/ or/39/784.

[62] T. Hemsted. "Second and Third Millennium Reserves Development in African Basins," in T. Arthur, D. S. MacGregor and N. R. Cameron, (Eds.), Petroleum Geology of Africa: New Themes and Developing Technologies. London, UK: Geological Society, p. 241, 2003.

[63] United States Census Bureau, "2012: US Trade in Goods with Africa," Foreign Trade, Washington, DC: U.S. Department of Trade, available at www.census.gov/foreign-trade/balance/ c0013.html.

[64] SIPRI. (2019). the Stockholm International Peace Research Institute (SIPRI) data for 2015-2019.

[65] TASS. (2019). "Russia-Africa Summit to Bring Bilateral Ties to a New Level, Diplomat Says," TASS, May 28, 2019, available at https://tass.com/politics/1060405.

[66] Review of the Kremlin's press service digest (available on kremlin.ru) for the period from January 2015 to August 2019.

[67] The White House. (December 13, 2018). "Remarks by National Security Advisor John R. Bolton on The Trump Administration's New Africa Strategy," available at https://www.whitehouse.gov/briefings statements/remarks-nationalsecurity-advisor-ambassador-john-r-boltontrump-administrationsnew- africa-strategy/.

[68] N. Turse (August 13, 2019). "U.S. Generals Worry about Rising Russian and Chinese Influence in Africa, Documents Show," Intercept,

[69] D. Lamothe. (April 2, 2019). "U.S. Africa Command Nominee Cites Potential Russian and Chinese Threats to U.S. Interests in the Region," Washington Post.

[70] P. Goble. (June 14, 2018) "Moscow Quickly Expanding Ties to Africa," Eurasia Daily Monitor, 15(92), [online]. Available at: https://jamestown.org/program/moscow-quickly-expanding-ties-toafrica/.

[71] D. Abdi Latif. (2018) "Russia Is the Latest World Power Eyeing the Horn of Africa," Quartz Africa, [online]. Available at: https://qz.com/africa/1377434/russias-sergey-lavrov-confirmsplansfor-logistics-base-in-eritrea/.

[72] J. Burger. "The Return of Russia to Africa. The New African", pp. 14$21,2018$.

[73] A. Luhn and D. Nicholls. "Russian Mercenaries Back Libyan Rebel Leader as Moscow Seeks Influence in Africa". The Telegraph, 2019. 
Abdallah I. Haruna, received his B.A. in Philosophy and M.Phil in African Studies from the University of Ghana. Mr. Abdallah has also studied for the Master of Business Administration (MBA) degree at the University of South Wales, UK. He is currently a $\mathrm{PhD}$ candidate in International Relations at the Social Sciences University of Ankara, Turkey. He is also an adjunct lecturer in African Studies at the TurkeyAfrica Foundation. His research and teaching focus on the influence of Islam on indigenous religious practices in Africa, culture and development in Africa, migration and the safety of migrants, colonialism and colonial land policy, and African foreign policy analysis. Mr. Abdallah has published in peer-reviewed journals around the world. He completed a book based on tradition and religions in Africa, entitled Tradition and Religion in Africa: Exploring the Changing Roles of the Tindana in Dagbon. He has also co-authored a book on the plight of migrants in Ghana.

A. Abdul Salam, had his B.A. and M.Phil in Sociology with a concentration in Medical Sociology from the University of Ghana, Legon. He is currently a part-time lecturer at Madina Institute of Science and Technology, Ghana. Mr. Abdul-Rahaman has also served as a parttime lecturer at the School of Medicine and Health Sciences, University for Development Studies, Ghana, a senior tutor at the College of Distance Education, University of Cape Coast, Zenith College Campus, Accra, Ghana and a teaching assistant at the Department of Sociology, University of Ghana, Legon. Mr. Abdul-Rahaman currently studies for $\mathrm{PhD}$ in Health Policy and Management at the University of Ghana Business School. He is also a Founder and Manager of Maani Scientific Research Services. His teaching and research interests include health system performance and quality of healthcare delivery, access to medicines and health-seeking behavior and public policy. 